\title{
UNIVERSITYOF
}

FORWARD

THINKING

WESTMINSTER用

WestminsterResearch

http://www.westminster.ac.uk/westminsterresearch

\section{Serjeant Musgrave's Dance and the politics of possibility in two television adaptations}

Wyver, J.

This is a copy of the accepted author manuscript of the following article: Wyver, J. (2014) Serjeant Musgrave's Dance and the politics of possibility in two television adaptations. Critical Studies in Television, 9 (3), pp. 89-99.

The final definitive version is available from the publisher Sage at:

https://dx.doi.org/10.7227/CST.9.3.9

(C) The Author(s) 2014

The WestminsterResearch online digital archive at the University of Westminster aims to make the research output of the University available to a wider audience. Copyright and Moral Rights remain with the authors and/or copyright owners.

Whilst further distribution of specific materials from within this archive is forbidden, you may freely distribute the URL of WestminsterResearch: ((http://westminsterresearch.wmin.ac.uk/)).

In case of abuse or copyright appearing without permission e-mail repository@westminster.ac.uk 


\title{
Serjeant Musgrave's Dance and the politics of possibility in two television adaptations
}

\author{
$\underline{\text { Abstract }}$ \\ John Arden's stage play Serjeant Musgrave's Dance was adapted for British \\ television in a Granada Television production in 1961 and four years later in a \\ three-part BBC Schools version. Although received at its stage premiere in \\ 1959 with puzzlement the play has since been acknowledged as a key work of \\ modern political drama in Britain with its bold use of anti-naturalistic techniques \\ including heightened prose and the integration of ballads. This article explores \\ the politics of the play and considers the ways in which these were retained or \\ removed by the two processes of adaptation for television.
}

\section{Keywords}

adaptation, John Arden, political drama, television, theatre play

\section{Article}

Within six years of its 1959 premiere at London's Royal Court theatre John Arden's stage play Serjeant Musgrave's Dance was adapted twice for British television. A primetime ITV production by Granada Television in 1961 was followed four years later by a far lower-profile version in three parts made for BBC Schools. Although the initial Royal Court production opened to decidedly mixed notices, the play was soon recognised as a key work in the modern British drama revival strongly associated in the late 1950s with the Royal Court and dramatists including John Osborne, Arnold Wesker and Arden himself. The play has since been acknowledged as a key theatrical work engaging explicitly with imperialism and militarism, although its politics are recognised as complex and entwined with questions of form and style. In his survey English Drama since 1940 David lan Rabey is unequivocal in stating that, 'Musgrave represents and remains (distinctly and unusually) English theatre at its most profoundly radical.' (Rabey 2003, 66).

This article explores the politics of the play offered to theatregoers and considers the ways in which these ideas were retained or removed by the 
processes of adaptation for television. The stage play refuses the conventions of naturalism in a number of ways, including the use of heightened language and the integration of folk ballads, songs and dances, and it exploits a specifically theatrical device by which the audience becomes a group of townspeople harangued by the central character and threatened by a Gatling gun. Both the Granada and the BBC Schools productions simplify the plotting and displace key aspects of the play's radical stage techniques by reinstating conventional naturalism in language and performance. Yet both versions retain aspects of the play's complex critiques of militarism and imperialism, and the BBC Schools version especially achieves in its final moments a singular sense of a politics of possibility.

Serjeant Musgrave's Dance premiered at the Royal Court on 22 October 1959, the theatre having previously staged Arden's The Waters of Babylon in 1957 and Live Like Pigs the following year. When Musgrave opened, with lan Bannen in the title role, the reviews for Lindsay Anderson's production were mixed, with many of the responses being either bemused or hostile, and it achieved box office sales of just twenty-one per cent capacity. (Billington 2007, 116-7) The play is set in a snow-bound colliery town in the north of England during the nineteenth century. Four soldiers, led by the stern and inflexible 'Black Jack' Musgrave, arrive by barge just before the freezing of the canal cuts off communication with the world beyond. The town is in the midst of a bitter dispute between pit-owners and miners. The colliers assume Musgrave's men have been sent to strike-break, even though Musgrave gives out that their mission is recruitment. Prompted by a fatal incident in an Imperial context far away, Musgrave has in fact come to execute twenty-five of the townspeople. On the morning after their arrival, Musgrave and the soldiers hold a meeting in the main square, at which they unveil a Gatling gun directed at the inhabitants, who in the theatre are now the seated audience. But the planned killing is thwarted first by Annie, a young woman who had been the lover of Billy Hicks, a dead colleague of the soldiers' colleagues, and then the arrival of dragoons who thanks to a thaw have been able to reach the town. 
After the Royal Court premiere a number of successful provincial productions were mounted as well as the 1961 Granada presentation, and there was a rapid shift in the dominant critical response to Arden's play. By early 1962 lan Rodger could celebrate Serjeant Musgrave's Dance as one of 'the two most important plays of the nineteen-fifties' (along with Look Back in Anger). (Rodger 1962, 487). In 1965, Jane Howell directed a Royal Court revival of Arden's play which was greeted by almost unanimously positive notices. A decade later, Albert Hunt wrote that, 'Serjeant Musgrave's Dance is now generally accepted as John Arden's masterpiece.' (Hunt 1974, 52-3). For Hunt, what he identifies as initial 'misunderstanding' between Arden and his critics arose from the latter's misrecognition of the politics of form that underpins all of the writer's work. To undermine conventional responses to the theatre, Hunt argues, Arden is making demands on his audience by grounding his style in the English ballad tradition, by employing anti-illusionist techniques such as the inclusion alongside naturalistic prose dialogue of songs and heightened verse, and by a resistance towards techniques that offer easy identifications for the audience with the views of one or more of the characters. Rather than the 'theatre of persuasion' offered by a theatre focussed above all on illusion, Hunt argues that Arden's theatre, like that of Brecht and Shakespeare, 'is a theatre of scepticism and questioning'. (ibid. 28) The theatre of illusion can offer only a simplified view of life, whereas Arden's theatre is built around contradictions and the clash of opposites.

John Arden himself provided a commentary on the play, both in an Introduction to the published text and in a number of interviews. He noted that the writing was in part prompted by an incident in Cyprus, in October 1958, when the island was occupied by British troops. 'A soldier's wife was shot in the street by terrorists' he explained in a 1961 interview, 'and according to newspaper reports $[\ldots]$ - some soldiers ran wild at night and people were killed in the rounding-up. The atrocity which sparks off Musgrave's revolt, and which happens before the play begins, is roughly similar.' (Arden 1961, 31). The play was written as the British Empire, of which Musgrave and his men are servants, was being dismantled in an often-violent process of decolonisation. In 1956 the 
Suez Crisis had underlined how marginal Britain's imperial aspirations were to the new power blocs of the post-war world. For Catherine Itzin in 1980 the postcolonial politics of the play revealed 'the results of an imperialist war waged by a capitalist society, and clear connections were drawn between capitalist economics and war.' (Itzin 1980, 28-9).

Reflecting on a different historical context, Arden stressed the importance to the play of the poetic tradition of English ballads. Sketching a line through Chaucer, Shakespeare, Dickens and Hardy as well as 'traditional poetry, some of it oral, some of it printed and hawked at street-corners, some of it sung from the stages of the music-halls,' Arden suggested that, 'this tradition is the one that will always in the end reach to the heart of the people. [...] As seen through the eyes of the sort of writers that I have mentioned, the English prove to be an extraordinarily passionate people, as violent as they are amorous, and quite astonishingly hostile to good government and order.' (Arden 1965, 126) This ballad tradition influenced the overall shape of Serjeant Musgrave's Dance, its story and its characters (such as Annie, abandoned by her man 'gone for a soldier'), as well as the integration throughout of traditional songs that sit alongside the action, comment on it but are not straightforwardly integrated. Sections of heightened verse are employed in a similar manner. Also linked to this ballad tradition is the play's use of strong colours, both in the imagery of the text and in the stage spectacle. Black playing-cards, 'rose-red' blood, gold coins, green apples are scattered in a verbal landscape defined by the white of the snow and the black of the coal. Arden felt that too many contemporary theatre productions, including that at the Royal Court of his own Live Like Pigs, were grey. 'I suddenly wanted to write a play,' Arden explained, 'with a visual excitement as well as a verbal one. I visualised the stage full of scarlet uniforms, and began to get interested from there.' (Arden 1961, 40) The play's visual excitements also include elements of unabashed theatrical spectacle, such as an elaborate clog-dance, a comedic sequence of drunken miners being drilled by the Chorus-like 'Bargee', and Musgrave's own manic dance towards the close as he hoists the skeleton of Billy Hicks to display it to the assembled citizens - or rather to the audience watching from the auditorium. 
The play is inscrutable and ambiguous, as are several of the main characters, including Musgrave and Annie, even as it aims to achieve the clarity and immediacy of a ballad. Crucial information about the intent and motivations of Musgrave and his men is withheld until almost the last moments, and sympathy for Musgrave's revulsion against the violence he has witnessed shifts to horror as his proposed solution, which is to execute five times the number of those who were killed in the soldiers' raids overseas, becomes apparent. Although it has been interpreted as nihilistic, as advocating violent revolution and as a paean to pacifism, for Arden the play has a more nuanced 'moral' which lies with the words and actions of Annie and of the innkeeper Mrs Hitchcock, and of one of the soldiers, Private Attercliffe. The final lines of the stage text - tentative and questioning, but with a vision of a better world to come - are spoken by Attercliffe to Musgrave as they both wait to be hanged: 'They're going to hang us up a length higher nor most apple-trees grow, Serjeant. D'you reckon we can start an orchard?' (Arden 1960, 104)

In his study of post-war British drama 1956 and All That, Dan Rebellato is ambivalent about the force and value of the play's conclusion. 'The revulsion from war is unmistakable,' he writes, 'but the play equivocates dramatically. [...] Despite Arden's own professed pacifism, the play can only offer a sense that such an ideal is impossible to sustain.' (Rebellato 1999, 17) Arden, however, later characterised the political intent of the play differently. 'I always resent plays in which the audience is brought in by the author to take one side of the argument,' he said in 1966. 'I feel that the extremely involved problems that we are up against today - war, sex, or whatever - are so complicated that you can't just divide them up into black and white. It is the job of the playwright to demonstrate the complexity, to try to elucidate it by the clarity of his demonstration. But to go further and start deciding for his audience is rather presumptuous.' (Wager 1966, 46) So to what extent was this 'clarity of demonstration', which in Musgrave is carried in a ballad play that is both simple and deeply mysterious, and that works with a strong sense of explicit theatricality, achieved in the two television adaptations produced in October 1961 by Granada Television and in November 1965 by BBC Schools? 
These two adaptations were not the first of John Arden's plays to be shown on British television, although to date the latter has been the last. ${ }^{1}$ Soldier, Soldier was written for the BBC as a television play in 1958, but it reached the screen on 16 February 1960, four months after Musgrave's Royal Court premiere. Transmission at this point ensured that it was inevitably seen through a lens focussed by the later play, not least because it tells of a soldier who pitches up in a northern town and befriends a family whose son, a member of his own regiment, is missing. Making extensive and effective use of the traditional song that gave the play its title, Soldier, Soldier was directed for television by Stuart Burge, who subsequently directed the Granada presentation of Musgrave. The production won a prize associated with the prestigious Prix Italia, which ensured that the BBC commissioned a second script from Arden. But the making of Wet Fish (broadcast 3 September 1961), directed by Peter Dews, was a dispiriting experience for the playwright. After Wet Fish there were to be no further original scripts for television, although on 11 April 1965 the BBC broadcast Arden's Ironhand, an adaptation of an eighteenth-century play by Goethe. Granada's studio production of Serjeant Musgrave's Dance was shown in the Play of the Week strand on the ITV Network at 9.35pm on 24 October 1961, almost exactly two years after the Royal Court premiere. In its early months, back in November 1956, the Manchester-based contractor for the commercial network had shown a studio version of the Royal Court's production of John Osborne's Look Back in Anger. The company's adventurous drama output since then had included plays by Arthur Miller, Eugene O'Neill, Sean O'Casey and Marguerite Duras, and in 1961 Granada offered television productions of Harold Pinter's The Dumb Waiter and The Room; both plays had been seen at the Royal Court in March 1960.

A feature in TV Times noted the London production of Serjeant Musgrave's Dance 'won for John Arden an award for the Most Promising Playwright of

\footnotetext{
${ }^{1}$ Extracts from Jane Howell's 1965 Royal Court revival of Serjeant Musgrave's Dance were also included in an episode of the Associated-Rediffusion documentary series Take It from the Top. Broadcast on 3 January 1966, the programme combined behind-the-scenes filming of the production with extracts featuring Iain Cuthbertson as Serjeant Musgrave and Ronald Pickup as Private Hurst.
} 
1959' (Anon. 1961a, 11) but the play's theatrical genesis was not acknowledged on-screen. Freda Jackson (Mrs Hitchcock), Donal Donnelly (Private Sparky) and Stratford Johns (The Mayor) reprised their roles from the original Court production, while Patrick McGoohan took over the role of Musgrave. Two commercial breaks divided the three acts of the play, which had a screen time of 78 minutes; this compares to a running time of around 150 minutes in the theatre. The anonymous television critic for The Times praised the play in this new version:

Its true quality was more apparent than ever in last night's independent television production, partly because of the superbly disciplined intensity of Mr. Stuart Burge's production [...] and partly because Mr. Arden had done some revision as well as some adaptation, making the plot development clearer and pruning the slow and careful scene-setting which to some tastes kept the theatre audience too much in the dark for too long about the play's real subject. (Anon. 1961b, 13)

The TV Times listing (although not the on-screen credits) notes that the play has been 'adapted for television by the author', and a comparison with the published text of the original reveals that the Granada production represents a substantial rewriting. A year or so after the broadcast, John Russell Taylor noted that

Arden himself has remarked on the confusing nature of the churchyard plotting scene, and in his television adaptation achieved a clarification which might well be used in further stage productions.[...] Arden's own television version of Serjeant Musgrave's Dance managed to make sense to millions where three years before even the London theatre critics were nonplussed. (Taylor 1969, 83, 91)

Apart from Russell Taylor's brief comments, the Granada production is almost entirely absent in the extensive literature on Arden and the play, and the few mentions it does achieve are sometimes misleading. ${ }^{2}$ Albert Hunt's Arden: $A$ Study of his Plays mis-states the year of the Granada presentation and has the broadcast as 'on BBC Television' (Hunt 1974: 14). The BBC Schools broadcast

\footnotetext{
${ }^{2}$ As far as can be determined, the television script has never been played on the
} stage. 
is included in neither the timeline in Hunt's book nor in the Chronology of the Methuen Student Edition of the play, first published in 1982 (Arden 1982)

The play's first scene with the soldiers playing cards is radically truncated in the Granada production, and the songs from both Sparky and the Bargee are the first of many to be cut from the original. The soldiers parade into town accompanied by an uncanny electronic organ score, and the opening lines of Act One Scene Two are also cut back. Annie's first speech in verse, 'l'll tell for what a soldier's good...' is spoken forcefully, with the camera closing in to a tight single shot. There are also a number of small changes to the dialogue that focus the drama more tightly on the mystery of why Musgrave has come to the town. Act One Scene Three takes place in the town's snow-covered cemetery and is the sequence in which William Brodie's design achieves the most distinctive visual style. Missing, inevitably, from the monochrome broadcast is the theatrical impact of the scarlet uniforms, but in this scene the images have echoes of the paintings of L.S. Lowry, which Arden suggested 'might suggest a suitable mood' for the play's theatrical designs (Arden 1960, 5). The later part of this scene is substantially re-written to be far more explicit about the soldiers' plans, as Private Attercliffe says:

Get the people set out in the market-place, tell them we're recruiting, show them the weapons. Glamorise them with the glory of war! Then when we've done that, detach twenty-five, hold them under guard and say, This is what we've gone and done, these are our hostages, we're holding them to ransom, we say it to the town and we say it to the whole country, the newspapers, parliament, what about the Queen? If you save these twenty-five, you'll all save yourselves. To stop the killing, Stop it. Not only does this new, detailed explanation outline what is envisaged far earlier than in the stage version, but it also appears, both here and later, to be how Musgrave himself in the adaptation believes things will play out. 'Five men have died,' Musgrave says in a new version of a private prayer, 'twenty-five must be taken.' In the stage play, by contrast, while taking hostages is Attercliffe's plan, Musgrave is determined from the start to kill the twenty-five. There are elements of ambiguity in both the stage text and the Granada 
recording, but the latter appears, until the closing moments, to propose a significantly less extreme remedy 'to stop the killing'.

In the theatre in Act Two Scene Three, as the printed stage directions detail, 'The stage is divided into two discreet acting areas.' (Arden 1960: 56) Musgrave is in bed upstage while downstage is the stable where the other three soldiers are to sleep. The Granada version separates the spaces and intercuts the action - Annie visiting the soldiers in turn, followed by the fight that leads to Sparky's death, while Musgrave reads his bible and is then afflicted with nightmares - which on stage takes place in parallel. Musgrave's fear of female sexuality is also emphasised in the television script. The key shift here, however, from stage to screen, is the treatment of Annie's visit to each of the soldiers in turn. On stage, this should have the quality of a ballad, of a reenactment of a timeless fable. On television, however, in the absence of any attempt by Stuart Burge at stylisation, the drama falls back on the conventions of naturalism, which here simply make for a scene that comes across as unconvincing. Any suggestion of the mythical that might be associated with Annie is buried beneath the earthy sexuality (or at least what could pass for such on ITV in 1961) of Jeanne Hepple's conventional characterisation.

The Act Three climax takes place in the town square and, as already noted, the theatre audience take the place of the townspeople so that 'as there is no crowd, the speeches are delivered straight out to the audience.' (Arden 1960, 76) But the Granada production re-instates the crowd, with the camera offering a first shot from above of colliers and others milling around. The fundamental theatrical conceit of direct threat is lost, and with it much of the play's dark and disturbing power. Even so, Musgrave's rhetoric is impressive, especially as given an on-the-edge intensity by McGoohan's performance that here, as previously, is pitched at a different register to the small-screen naturalism of the rest of the cast. His 'dance', however, together with his song as Billy Hicks' skeleton is raised, is more muted than is suggested in the text, where 'his face is contorted with demoniac fury'. On stage, orchestrated by the manic energy of Musgrave, this scene can achieve a disturbing sense of ritual, whereas 
McGoohan's performance, constrained by and observed on a small screen, is almost inevitably read within the conventions of naturalism - and as a consequence seems slightly ridiculous. Only now in the Granada version does Musgrave's plan to kill twenty-five of the townsfolk become clear, prompting spirited opposition from Attercliffe and Private Hurst, but the idea is tightly associated with Musgrave's personal madness. This shifts it away from the (perhaps marginally) broader grounding that it has amongst the group of soldiers in the original text. Similarly de-emphasised in the Granada production is the attempt to make a common cause with striking miners. The social and the political imperatives of the text are displaced by a greater stress on Musgrave's lunacy underlined by repeated close-shots of McGoohan's distorted features. Yet at the same time, there is a clearer identification of the cause of the lunacy, which is spoken by Hurst in the stage text and by Musgrave on screen: 'We've earned our living by beating and killing folks like yourselves in the streets of their own city, and it's driven us mad!'

Annie's appearance on stage has the symbolic quality of a deus ex machine, for she descends by a ladder from an upper-story window. In the television studio she simply wanders in through the crowd, but her spoken intervention is much as it is in the text, although the arrival of the dragoons that follows is significantly shortened. Similarly truncated too is the restoration of 'normality' for the community, which in the theatre is the last of the stage set-pieces involving the Bargee (whose role throughout the television version has been minimised) handing out free beer, the gradual take-up of a mindless, repetitive song and the symbolic joining together of the Mayor, the Parson, the Constable and the colliers (although not their leader, Walsh) dancing in a circle that is also, as the stage directions describes it, 'a chain'. In the television version, as in the stage text, Walsh bitterly confronts Musgrave, saying 'We're back where we were. So what do we do?' But on screen the dance and song are reduced to a distant backdrop behind the bemused final words of a fore-grounded Musgrave. This last scene, in which Attercliffe sings his song and speaks the closing line, is played as a continuation of the one before, while on stage there is a clear separation in time. Musgrave and Attercliffe are chained to a gun- 
carriage which pulls them out of shot, and the camera pans round as the dancers come back into shot, still singing as they snake through the town. At the very end there is the sound of marching, tramping feet, then the credits roll, and the dance continues as the distorted organ score returns on the soundtrack. Attercliffe's vision is undercut and the final effect for the ITV audience is not of the potential for a better world but rather of the securely reinstated status quo.

If the Granada version of Serjeant Musgrave's Dance in 1961 responded to the play's growing critical acceptance, the BBC Schools production four years later reflected its embrace by examination boards concerned to put vivid contemporary drama before secondary school pupils. It also followed soon after Jane Howell's successful Royal Court revival of the play. The new adaptation of Serjeant Musgrave's Dance was first shown in three half-hour weekly episodes from Tuesday 26 October 1965 at 2.05pm in BBC1's dedicated schools slot. Transmission details were included in Radio Times and in newspaper listings, and general viewers could watch, although there appears to have been no feature coverage and, as far as can be determined, no reviews. Andrew Keir took the role of Musgrave, with Jessie Evans as Mrs Hitchcock and Rosemary Leach as Annie. The adaptation is credited to producer Michael Simpson, who was a regular BBC Schools producer, and who appears to have based his script on the original stage text and not on Arden's 1961 revision.

The production values of the BBC Schools production are more modest than those deployed by Granada, and the studio setting is clearly more cramped. The cast members in common between the two productions are Denis Carey, who plays Attercliffe in both, and Derek Newark, who takes the role of the Dragoon Sergeant in the Granada production and that of Private Hurst for BBC Schools. The BBC Schools production makes dialogue cuts throughout, but most the key events of the original text are retained as is their ordering. Act Two Scene Two, however, in which the colliers attempt to steal the Gatling gun, is cut completely. In the first episode, in addition to the new ballad detailed below, effective use is made of direct-to-camera address by the actors playing 
the Mayor and Walsh, who sketch in their short speeches background information that in Arden's text is given more obliquely in exchanges between Musgrave and the other characters. The same technique is employed for Annie's verse, 'l'll tell you for what a soldier's good...' which very successfully fulfils Arden's wish for the verse sections to be clearly distinguished from the prose speeches. The displacement of theatrical address on to the specifically televisual technique of direct-to-camera address largely disappears from the adaptation after the first episode, although Part Three opens with a close-up shot of the Bargee shouting into the camera 'Hip hip hooray!' Like the Granada production, this part also reinstates the crowd for the town meeting and there is similarly no attempt to find a screen equivalent for playing the speeches and the threat of the Gatling gun direct to the theatre audience. Once the dragoons have arrived, the Bargee sings 'Michael Finnegan' but there is no communal dance, in part because the budget and the constrained studio space could almost certainly not accommodate this.

The closing scene, in contrast to the Granada version, is kept distinct from the dancing, and the following lines spoken by Mrs Hitchcock (who delivers them looking almost directly into the lens) are placed later than in the stage text, after Attercliffe's song and just before his final words:

Those men out there, they're hungry. They've got no time for you, not now. One day they'll be full though, and then they'll remember your words. Let's hope it, any road.

Immediately afterwards, Attercliffe says

They're going to hang us up a length higher nor most apple-trees grow,

Serjeant. D'you reckon we can start an orchard?

There is a close-up shot of Musgrave looking pensive and the credits roll, leaving the viewer with a stronger sense of the vision of change and of the possibility of its realisation - which in the Granada production appears to be closed off by the mindless singing and dancing. A further notable difference between the two television adaptations is the inclusion at the top of Part One of the BBC Schools production of a five-minute sequence featuring a ballad introduction. This was written by producer Michael Simpson, and was arranged 
and sung by the folk singer Martin Carthy. The ballad sketches the back-story to the arrival of the soldiers in the town, setting this firmly in the context of Victorian Imperialism. Accompanied by line illustrations suggestive of the style of Käthe Kollwitz, the song reinforces Arden's vision for the play but at the same time establishes Musgrave as a wholly sympathetic character, with no sense of the manic desperation behind his arrival in the colliery town.

In large part as a consequence of this opening, the BBC Schools adaptation is linked more strongly to the tradition that, for Arden, 'will always in the end reach to the heart of the people'. Yet the elements of this tradition that make the play so distinctive - the interpolation of ballads and sections of heightened verse and the elements of stage spectacle - are diminished in the translation to television, where the imperatives of naturalism recuperate much - but not all - of this potential. In the Granada production the obscurities of plot and motivation are explicated more carefully by the playwright's extensive re-writing, although the later BBC Schools version achieves narrative clarity without the need for such changes. Much of the critique of militarism, in the imperial context of Victorian Britain and in the imminently post-colonial world of the 1960s, is retained in both plays, and is expressed with persuasive power by Andrew Keir and, most especially, by Patrick McGoohan. Yet the single most disturbing aspect of the stage spectacle, which has the live audience sitting facing a Gatling gun for almost a third of the drama, is lost in both adaptations because neither finds a televisual equivalent for this inherently theatrical conceit. Nor could either the Granada Television or the BBC Schools production be described as 'profoundly radical', and yet each expresses certain aspects of the politics of possibility given form by the original text. And in its playing of the very final moments of the drama, Michael Simpson's version for BBC Schools offers the viewer a far more hopeful vision of an imagined world without war.

\section{References}

Play of the Week: Serjeant Musgrave's Dance. 1961. Broadcast 24 October by ITV. Directed by Stuart Burge and written by John Arden. 
Drama: Serjeant Musgrave's Dance. 1965. Three episodes broadcast 26 October, 3 November, 10 November by BBC1. Produced by Michael Simpson, and written by John Arden.

Soldier, Soldier. 1960. Broadcast 16 February by BBC Television. Produced by Stuart Burge and written by John Arden.

The Sunday-night Play: Wet Fish. 1961. Broadcast 3 September by BBC Television. Produced by Peter Dews and written by John Arden.

Anon. 1961a. 'Serjeant Musgrave's Dance', TV Times, 22 October: 11.

--- 1961b. 'Clearer Serjeant Musgrave', The Times, 25 October: 13.

Arden, John. 1960a. Serjeant Musgrave's Dance, London: Eyre Methuen.

--- 1961. 'Building the Play: An Interview with the Editors', Encore 32, 8 (4): $22-$ 41.

--- 1965. 'Telling a True Tale'. In The Encore Reader: A Chronicle of the New Drama edited by Charles Marowitz, Tom Milne and Owen Hale, 125-9. London: Methuen.

--- 1982. Serjeant Musgrave's Dance: Methuen Student Edition. London: Methuen.

Billington, Michael. 2007. State of the Nation: British Theatre Since 1945. London: Faber and Faber.

Hunt, Albert. 1974. Arden: A Study of his Plays. London: Eyre Methuen.

Itzin, Catherine. 1980. Stages in the Revolution: Political Theatre in Britain since 1968. London: Eyre Methuen.

Rabey, David lan. 2003. English Drama Since 1940. London: Pearson Education.

Rebellato, Dan. 1999. 1956 and All That: The Making of Modern British Drama. London and New York: Routledge.

Rodger, lan. 1962. 'Two Milestones', The Listener, 15 March: 487.

Taylor, John Russell. 1963. Anger and After: A Guide to the New British Drama. revised ed. London: Penguin Books.

Wager, Walter. 1966. 'Who's for a Revolution? Two Interviews with John Arden', The Tulane Drama Review, 11 (2): 42-8.

Wardle, Irving. 1960. 'Jungle of Arden', The Listener, 25 February: 362. 